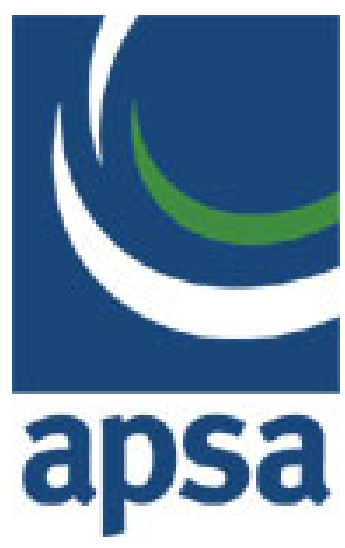

The New Institutionalism: Organizational Factors in Political Life Author(s): James G. March and Johan P. Olsen

Source: The American Political Science Review, Vol. 78, No. 3 (Sep., 1984), pp. 734-749

Published by: American Political Science Association

Stable URL: http://www.jstor.org/stable/1961840

Accessed: 06/08/2014 23:05

Your use of the JSTOR archive indicates your acceptance of the Terms \& Conditions of Use, available at http://www.jstor.org/page/info/about/policies/terms.jsp

JSTOR is a not-for-profit service that helps scholars, researchers, and students discover, use, and build upon a wide range of content in a trusted digital archive. We use information technology and tools to increase productivity and facilitate new forms of scholarship. For more information about JSTOR, please contact support@jstor.org. 


\title{
The New Institutionalism: Organizational Factors in Political Life
}

\author{
JAMES G. MARCH \\ Stanford University \\ JOHAN P. OLSEN \\ University of Bergen
}

\begin{abstract}
Contemporary theories of politics tend to portray politics as a reflection of society, political phenomena as the aggregate consequences of individual behavior, action as the result of choices based on calculated self-interest, history as efficient in reaching unique and appropriate outcomes, and decision making and the allocation of resources as the central foci of political life. Some recent theoretical thought in political science, however, blends elements of these theoretical styles into an older concern with institutions. This new institutionalism emphasizes the relative autonomy of political institutions, possibilities for inefficiency in history, and the importance of symbolic action to an understanding of politics. Such ideas have a reasonable empirical basis, but they are not characterized by powerful theoretical forms. Some directions for theoretical research may, however, be identified in institutionalist conceptions of political order.
\end{abstract}

In most contemporary theories of politics, traditional political institutions, such as the legislature, the legal system, and the state, as well as traditional economic institutions, such as the firm, have receded in importance from the position they held in the earlier theories of political scientists such as J.W. Burgess or W.W. Willoughby, economists such as Thorstein Veblen or John R. Commons, and sociologists such as Max Weber. From a behavioral point of view, formally organized social institutions have come to be portrayed simply as arenas within which political behavior, driven by more fundamental factors, occurs. From a normative point of view, ideas that embedded morality in institutions, such as law or bureaucracy, and that emphasized citizenship as a foundation for personal identity, have given way to ideas of moral individualism and an emphasis on conflicting interests.

In recent years, however, a new institutionalism has appeared in political science. It is far from

Received: October 6, 1983

Accepted for publication: December 6, 1983

This research has been supported by grants from the Norwegian Research Council for Science and Humanities, the Norwegian Ministry of Consumer Affairs and Government Administration, the Mellon Foundation, the Spencer Foundation, the Stanford Graduate School of Business, and the Hoover Institution. We are grateful for comments by Julia W. Ball, Michael D. Cohen, Stephen D. Krasner, Martin Landau, Todd LaPorte, W. Richard Scott, and William Siffin. coherent or consistent; it is not completely legitimate; but neither can it be entirely ignored. This resurgence of concern with institutions is a cumulative consequence of the modern transformation of social institutions and persistent commentary from observers of them. Social, political, and economic institutions have become larger, considerably more complex and resourceful, and prima facie more important to collective life. Most of the major actors in modern economic and political systems are formal organizations, and the institutions of law and bureaucracy occupy a dominant role in contemporary life.

Attention to political institutions has increased in the literature on legislatures (Shepsle \& Weingast, 1983), budgets (Padgett, 1981), public policymaking (Ashford, 197": Scharpf, 1977), local government (Kjellberg, 1975), and political elites (Robins, 1976). It is manifest in studies of the origin of the state (Wright, 1977) and the development of national administrative capacity (Skowronek, 1982), in analyses of the breakdown of democratic regimes (Potter, 1979), and in discussions of corporatism (Berger, 1981; Olsen, 1981; Schmitter \& Lehmbruch, 1979). It is reflected in the Marxist rediscovery of the state as a problem in political economy (Jessop, 1977) and of the importance of organizational factors for understanding that role (Therborn, 1980). It is present in studies of formal organizations and particularly in studies of the place of such organizations in the implementation of public policy (Hanf \& Scharpf, 1978). It is visible in attempts to link the study of the state to natural science (Masters, 1983) and to the humanities 
(Geertz, 1980), as well as in a renewed interest in making historical-comparative studies of the state (Evans, Rueschemeyer, \& Skocpol, 1983; Hayward \& Berki, 1979; Krasner, in press).

In this article we examine some aspects of these developments and their implications for developing a theoretical understanding of how political life is organized. We approach the task from the perspective of students of formal organizations. The argument, however, extends beyond organization theory to a more general view of the place of institutions in politics and the possibilities for a political theory that is attentive to them.

\section{Theoretical Styles of Contemporary Political Science}

Although the concept of institution has never disappeared from theoretical political science, the basic vision that has characterized theories of politics since about 1950 is (a) contextual, inclined to see politics as an integral part of society, less inclined to differentiate the polity from the rest of society; (b) reductionist, inclined to see political phenomena as the aggregate consequences of individual behavior, less inclined to ascribe the outcomes of politics to organizational structures and rules of appropriate behavior; (c) utilitarian, inclined to see action as the product of calculated self-interest, less inclined to see political actors as responding to obligations and duties; (d) functionalist, inclined to see history as an efficient mechanism for reaching uniquely appropriate equilibria, less concerned with the possibilities for maladaptation and non-uniqueness in historical development; and (e) instrumentalist, inclined to define decision making and the allocation of resources as the central concerns of political life, less attentive to the ways in which political life is organized around the development of meaning through symbols, rituals, and ceremonies.

\section{Politics as Subordinate to Exogenous Forces: Contextualism}

Historically, political scientists and political philosophers have tended to treat political institutions, particularly the state, as independent factors, important to the ordering and understanding of collective life (Heller, 1933). Modern political scientists, with few exceptions, have not. The state has lost its position of centrality in the discipline; interest in comprehensive forms of political organization has declined; political events are defined more as epiphenomena than as actions necessary to an understanding of society; politics mirrors its context (Easton, 1968).

The most conspicuous contextual factor cited in recent writing is the social class structure. The social stratification of a modern society with its associated distribution of wealth and income has obvious major effects on political events. Class differences translate into political differences with great reliability across time and across cultures; differences in the organization and ideology of social class seem to lead to predictable differences in political organization and institutions (Tilly, 1978). Other analyses at the same level of aggregation make the structure and process of politics a function of physical environment, geography, and climate; of ethnicity, language, and culture; of economic conditions and development; or of demography, technology, ideology, or religion. Plausible arguments which make political life a derivative of one or more of these broad contextual forces have been developed, and it is not hard to find empirical data to support the arguments. Although there are a number of relatively precise contextual theories, the major theoretical significance of these ideas from the present point of view is less the specific forms of the theories than their general inclination to see the causal links between society and polity as running from the former to the latter, rather than the other way around. It is assumed that class, geography, climate, ethnicity, language, culture, economic conditions, demography, technology, ideology, and religion all affect politics but are not significantly affected by politics.

\section{The Macro Consequences of Micro Behavior: Reductionism}

Historically, political theory has treated political institutions as determining, ordering, or modifying individual motives, and as acting autonomously in terms of institutional needs. In contrast, substantial elements of modern theoretical work in political science assume that political phenomena are best understood as the aggregate consequences of behavior comprehensible at the individual or group level.

Such theories depend on two presumptions. The first presumption is that a political system consists of a number (often a large number) of elementary actors. Human behavior at the level of these elementary actors may be seen as conscious, calculated, and flexible, or as unconscious, habitual, and rigid. In either case, the preferences and powers of the actors are exogenous to the political system, depending on their positions in the social and economic system. The second presumption is that collective behavior is best understood as stemming from the (possibly intricate) interweaving of behavior understandable at a lower level of aggregation. Discovering, or deducing, the collective consequences may be difficult, even impossible; but the central faith is that 
outcomes at the collective level depend only on the intricacies of the interactions among the individual actors, that concepts suggesting autonomous behavior at the aggregate level are certainly superfluous and probably deleterious.

Within such a perspective, for example, the behavior of an organization is the consequence of the interlocking choices by individuals and subunits, each acting in terms of expectations and preferences manifested at those levels (Niskanen, 1971). The behavior of a market is the consequence of the interlocking choices by individuals and firms, each acting in terms of a set of expectations and preferences manifested at those levels (Stigler, 1952). It is not necessary that the micro processes involve choice, of course. Aggregate behavior in a group can be defined as the consequence of the interlocking of trial-and-error learning occurring at the individual level (Lave \& March, 1975). Or the aggregate behavior of an industry can be defined as the consequence of the interlocking of standard operating procedures and accounting rules followed at the level of the individual firm (Nelson \& Winter, 1982).

There is nothing intrinsic to a perspective that emphasizes the macro consequences of micro actions which requires that the elementary units be individuals. All that is required is that the behavior of a more comprehensive system be decomposable to elementary behaviors explicable at a less comprehensive level. In practice, however, in most of the social sciences, the actions of individual human beings are considered to determine the flow of events in a larger social system. Outcomes at the system level are thought to be determined by the interactions of individuals acting consistently in terms of the axioms of individual behavior, whatever they may be. Thus, we make assumptions about individual consumers to understand markets, about voters to understand politics, and about bureaucrats to understand bureaucracies.

The two best-specified theories of aggregate behavior in the social sciences, the economic theory of markets and the ecological theory of environmental competition, exemplify the modern style. Consider the theory of markets. Within this theory we find individual consumers, each attempting to make purchases at the best possible prices considering his or her own preferences and alternatives, and individual producers, each attempting to make production and pricing decisions that result in the best possible return considering his or her own preferences and alternatives. The behavior of the market is assumed to be understandable as a consequence of these individual actors making choices that, in aggregate, fit together into market phenomena. Consider similarly the ecological theory of environmental competition. Within this theory we find individual species, each adapting to an environment through survival, mutation, and reproduction. Selection and changes in population distributions within the environment are assumed to be understandable as consequences of the actions of individual actors that, in combination with the actions of others and the potential capacity of the environment, produce a distribution of types.

\section{Action as the Making of Calculated Decisions: Utilitarianism}

Historically, political science has emphasized the ways in which political behavior was embedded in an institutional structure of rules, norms, expectations, and traditions that severely limited the free play of individual will and calculation (Wolin, 1960). In contrast, modern political science has, for the most part, described political events as the consequence of calculated decisions. Not just in political science, but throughout modern theoretical work in the social sciences, the preeminent vision of human behavior is a vision of choice. Life is characterized as deliberate decision making.

The details of the choice metaphor vary from one treatment to another, but the characteristic form is one that assumes choices stem from two guesses about the future. The first is a guess about the uncertain future consequences of possible current action. Decision theorists recognize that human limitations may restrict the precision of the estimates, that the estimates may be biased, and that the information on which the estimates are based may be costly; but information about probable consequences is assumed to be important to a choice. From this assumption comes an emphasis on the power of information and expertise (Crozier, 1964) and the importance of reliable and unbiased information sources (Nisbet \& Ross, 1980). Although numerous psychological experiments have indicated that the guesses of human subjects are biased (Kahneman, Slovic, \& Tversky, 1982), it has not been easy to formulate alternatives to the simple notion that the guesses of experienced humans are, on average, accurate. As a result, most theories of choice present decisions as being, on average, sensible. In their political versions, choice theories assume that, on average, voters vote intelligently with respect to their interests; legislators organize sensible coalitions, given their interests; and nation states voluntarily enter alliances that, on average, improve their positions.

The second guess on which intentional, antic. ipatory choice is based is a guess about a decisior maker's uncertain future preferences for possibl future outcomes. In any theory of deliberat 
choice, action depends on the decision maker's values. Since the consequences of interest are to be realized in the future, it is necessary to anticipate not only what will happen but how the decision maker will feel about those outcomes when they are experienced (March, 1978). The compexities of the second guess are largely ignored by theories of choice. In their standard forms, the theories assume that preferences are stable, thus that current preferences are good predictors of future preferences; that preferences are unambiguous and consistent, thus that a choice will be clearly indicated, given the first guess; and that preferences are exogenous, thus that whatever process generates preferences, it precedes choice and is independent of the choice process. In one of the best-developed forms of choice theories, these assumptions about preferences are taken as axioms, and preferences are discovered not by asking decision makers to report them but by defining a "revealed preference" function that satisfies the axioms and is consistent with choices made by a decision maker (Luce \& Raiffa, 1957). Although the empirical existence of consistent revealed preferences has been the subject of considerable debate (Becker \& Stigler, 1977; Kahneman, Slovic, \& Tversky, 1982), the theoretical idea forms the basis of extensive analytical development and empirical exploration.

\section{The Efficiency of History: Functionalism}

Historically, political theory has been ambivalent about the efficiency of history. Like other social scientists, students of political development have been inclined to accept an idea of progress, the more or less inexorable historical movement toward some more "advanced" level. At the same time, political histories have often emphasized the unique significance of a particular sequence of events or choices, the impact of a particular campaign strategy or speech, or the particular tactics of international negotiation. In modern usage, the terminology of progress has been largely replaced by a terminology of survival, but for the most part, in contemporary theoretical political science, institutions and behavior are thought to evolve through some form of efficient historical process.

An efficient historical process, in these terms, is one that moves rapidly to a unique solution, conditional on current environmental conditions, thus independent of the historical path. The equilibrium may involve a stochastically stable distribution or a fixed point, but we require a solution that is achieved relatively rapidly and is independent of the details of historical events leading to it. The assumption of historical effi- ciency is a standard, although usually not explicit, assumption of much of modern social science. Economic theories of markets and ecological theories of competition, for example, are concerned with the characteristics of an equilibrium, if one exists. They are used to predict differences (e.g., in markets, organizational structures, population, technologies) that will be observed, at equilibrium, in different environments. Similarly, some postwar theories of political parties see party orientation and organization as equilibrium solutions to problems of survival in a competitive political environment (Downs, 1957). The assumption of historical efficiency makes such theories largely indifferent to the behavioral reality of the micro processes that are assumed. For example, competition can be assumed to eliminate action that is inconsistent with the logic of survival. Examples include theories of market equilibria, such as those found in recent ideas of efficient capital markets (Sharpe, 1970); theories of organizational structure, such as those found in recent ideas of industrial organization (Williamson, 1978); and theories of political parties, such as those found in ideas of political economy (Olson, 1965).

History cannot be guaranteed to be efficient. An equilibrium may not exist. Even if there is an equilibrium, historical processes can easily be slow enough relative to the rate of change in the environment that the equilibrium of the process is unlikely to be achieved before the environment, and thus the equilibrium, changes. By assuming quickness, theories of political behavior avoid focusing on transient phenomena that might be less predictable and more subject to effects from the details of the processes involved. For example, when it is predicted that political parties will come to identical positions in an environment of singlepeaked voter preferences, it is assumed that party adjustment will be much more rapid than will be changes in voter preferences. Efficiency also requires that the equilibrium be unique and achievable. Processes with multiple equilibria are, of course, easily specified and frequently observed. What makes them unattractive is not their rarity, but their intractability and the indeterminacy of their outcomes. It is no accident that the most common principle of theories in the social sciences is the optimization principle, and that one of the greatest concerns in such theories is showing that a process has a unique optimum that is guaranteed to be achieved.

\section{The Primacy of Outcomes: Instrumentalism}

Historically, theories of political institutions portrayed political decision making primarily as a process for developing a sense of purpose, direc- 
tion, identity, and belonging. Politics was a vehicle for educating citizens and improving cultural values. Although there are exceptions, the modern perspective in political science has generally given primacy to outcomes and either ignored symbolic actions or seen symbols as part of manipulative efforts to control outcomes, rather than the other way around.

Modern polities are as replete with symbols, ritual, ceremony, and myth as the societies more familiar to anthropological tradition. Politicians announce public support for positions they fail to defend in private (Edelman, 1964). Legislators vote for legislation while remaining indifferent to its implementation (Pressman \& Wildavsky, 1973). Administrators solicit public participation in decision making in order to secure public support for policies to which they are already committed. Chief executives advocate reorganization of the public bureaucracy, announce plans for making reorganizations, and regularly abandon the plans (March \& Olsen, 1983). Information is gathered, policy alternatives are defined, and cost-benefit analyses are pursued, but they seem more intended to reassure observers of the appropriateness of actions being taken than to influence the actions (Feldman \& March, 1981).

In modern discussions of politics, these symbolic actions are characteristically portrayed as strategic moves by self-conscious political actors. Rituals and ceremonies are defined as windowdressing for the real political processes, or as instruments by which the clever and the powerful exploit the naive and the weak. The hiring of experts lends legitimacy to policies (Meyer \& Rowan, 1977); associating unpopular moves with popular symbols is reassuring (Edelman, 1964). Control over symbols is a basis of power, like control over other resources (Pfeffer, 1981a); and the use of symbols is part of a struggle over political outcomes (Cohen, 1974).

\section{Institutionalist Perspectives}

The new institutionalism is not peculiar to political science. Renewed interest in institutions is characteristic of recent trends in economics, which has discovered law, contracts, hierarchies, standard operating procedures, professional codes, and social norms (Akerlof, 1980). It is also seen in anthropology and sociology, although non-institutionalist visions never succeeded in those fields to the extent that they did in political science and economics. Nor are the institutionalist ideas entirely new. By labeling the collection of ideas "the new institutionalism," we mean to note the fact that there was indeed an "old institutionalism," that cycles in ideas have brought us back to considerations that typified earlier forms of theory in political science. We do not mean to suggest, however, that the new and the old are identical. It would probably be more accurate to describe recent thinking as blending elements of an old institutionalism into the non-institutionalist styles of recent theories of politics.

This new institutionalism can be presented and discussed as an epistemological perspective of profound importance to understanding social science, but for our purposes, it is more useful to define it in terms of a narrow collection of challenges to contemporary theoretical thinking in political science, a small set of relatively technical ideas of primary interest to professional students of political life. The ideas deemphasize the dependence of the polity on society in favor of an interdependence between relatively autonomous social and political institutions; they deemphasize the simple primacy of micro processes and efficient histories in favor of relatively complex processes and historical inefficiency; they deemphasize metaphors of choice and allocative outcomes in favor of other logics of action and the centrality of meaning and symbolic action. The ideas are not all mutually consistent. Indeed, some of them seem mutually inconsistent. For example, ideas based on the assumption that large institutional structures (e.g., organizations, legislatures, states) can be portrayed as rationally coherent autonomous actors are uneasy companions for ideas suggesting that political action is inadequately described in terms of rationality and choice.

\section{The Causal Position of Political Institutions}

Without denying the importance of both the social context of politics and the motives of individual actors, the new institutionalism insists on a more autonomous role for political institutions. The state is not only affected by society but also affects it (Katzenstein, 1978; Krasner, 1978; Nordlinger, 1981; Skocpol, 1979; Stephan, 1978). Political democracy depends not only on economic and social conditions but also on the design of political institutions. The bureaucratic agency, the legislative committee, and the appellate court are arenas for contending social forces, but they are also collections of standard operating procedures and structures that define and defend interests. They are political actors in their own right.

The argument that institutions can be treated as political actors is a claim of institutional coherence and autonomy. The claim of coherence is necessary in order to treat institutions as decision makers. From such a point of view, the issue is whether we wish to picture the state (or some 
other political institution) as making choice on the basis of some collective interest or intention (e.g., preferences, goals, purposes), alternatives, and expectations (Levi, 1981). There is no necessary answer to the question unless we impose one. Whether it makes pragmatic theoretical sense to impute interests, expectations, and the other paraphernalia of coherent intelligence to an institution is neither more nor less problematic, a priori, than whether it makes sense to impute them to an individual (Kahneman, 1982; March \& Shapira, 1982). The pragmatic answer appears to be that the coherence of institutions varies but is sometimes substantial enough to justify viewing a collectivity as acting coherently.

The claim of autonomy is necessary to establish that political institutions are more than simple mirrors of social forces. Empirical observations seem to indicate that processes internal to political institutions, although possibly triggered by external events, affect the flow of history. Programs adopted as a simple political compromise by a legislature become endowed with separate meaning and force by having an agency established to deal with them (Skocpol \& Finegold, 1982). The establishment of public policies, or competition among bureaucrats or legislators, activates and organizes otherwise quiescent identities and social cleavages (Olsen \& Saetren, 1980; Tilly, 1978). Policy experts within the political system develop and shape the understanding of policy issues and alternatives (Heclo, 1974).

Such phenomena are not routinely accommodated by modern political theory, which makes political outcomes a function of three primary factors: the distribution of preferences (interests) among political actors, the distribution of resources (powers), and the constraints imposed by the rules of the game (constitutions). Each of these is treated as exogenous to the political system. That is, preferences are developed within a society and transmitted through socialization, resources are distributed among political actors by some broad social processes, and rules of the game are either stable or change by a revolutionary intervention exogenous to ordinary political activities.

The idea that preferences are produced and changed by a process that is exogenous to the processes of choice is fundamental to modern decision theory. In the "revealed preference" version of the theory, preferences must be stable in order for the theory to be testable. In other versions, preferences can change, but choice itself does not produce a change in preferences. Conventional theories of markets, for example, picture advertising and experience as providing information about alternatives and their properties, not as af- fecting tastes. Similarly, conventional theories of politics assume that a voter's exposure to and choice of a candidate do not change that voter's preferences for various attributes that a candidate might possess, although they may change a voter's beliefs about which candidates possess which attributes. The new institutionalism, in company with most research on preferences, argues that preferences and meanings develop in politics, as in the rest of life, through a combination of education, indoctrination, and experience. They are neither stable nor exogenous (Cohen \& Axelrod, in press). If political preferences are molded through political experiences, or by political institutions, it is awkward to have a theory that presumes preferences are exogenous to the political process. And if preferences are not exogenous to the political process, it is awkward to picture the political system as strictly dependent on the society associated with it.

The contrast between the two kinds of notions is found most starkly in theories of political leadership. One classic idea of political leadership emphasizes the creation of winning political coalitions among participants with given demands (March, 1970). The leadership role is that of a broker: providing information, identifying possible coalitions, and facilitating side-payments and the development of logrolls. Such a view of leadership is implicit in the theory of the political process that has been developed in political science in recent decades. A second conception of leadership emphasizes the transformation of preferences, both those of the leader and those of the followers (Burns, 1978; Selznick, 1957). Leaders interact with other leaders and are coopted into new beliefs and commitments. The leadership role is that of an educator, stimulating and accepting changing worldviews, redefining meanings, stimulating commitments. Such a view is more conspicuous in the ideas of the new institutionalism.

The distribution of political resources is also partly determined endogenously. Political institutions affect the distribution of resources, which in turn affects the power of political actors, and thereby affects political institutions. Wealth, social standing, reputation for power, knowledge of alternatives, and attention are not easily described as exogenous to the political process and political institutions. Holding office provides participation rights and alters the distribution of power and access (Egeberg, 1981; Laegreid \& Olsen, 1978). The policy alternatives of leaders are not defined completely by exogenous forces, but are shaped by existing administrative agencies (Skocpol, 1980; Skocpol \& Finegold, 1982; Skowronek, 1982). The outcomes of the political 
process modify reputations for power, which in turn modify political outcomes (Enderud, 1976; March, 1966).

Finally, the third exogenous factor in conventional theories of politics, the rules of the game, is not really exogenous either. Constitutions, laws, contracts, and customary rules of politics make many potential actions or considerations illegitimate or unnoticed; some alternatives are excluded from the agenda before politics begins (Bachrach \& Baratz, 1962), but these constraints are not imposed full-blown by an external social system; they develop within the context of political institutions. Public agencies create rules and have them sanctioned by politicians (Eckhoff \& Jacobsen, 1960), and revolutionary changes are initiated and pursued by military bureaucrats (Trimberger, 1978).

\section{The Causal Complexity of Political History}

Theories of politics tend to assume a relatively uncomplicated intermeshing among the elementary units of a political system. There may be many individuals, groups, or classes involved, but they are relatively undifferentiated and their interactions are relatively simple. Empirical observations of political systems, on the other hand, often stress the institutional complexity of modern states (Ashford, 1977; Scharpf, 1977) and identify a rather complicated intertwining of institutions, individuals, and events. Alternatives are not automatically provided to a decision maker; they have to be found. Search for alternatives occurs in an organized context in which problems are not only looking for solutions, but solutions are looking for problems. Information about the consequences of alternatives is generated and communicated through organized institutions, so expectations depend on the structure of linkages within the system, as well as the ways in which biases and counter-biases cumulate (Simon, 1957a, b). Guesses about future preferences are developed within institutions dedicated to defining and modifying values and the meanings of actions (Cyert \& March, 1963; March \& Olsen, 1976). There are many such institutions, some nested within others, with multiple, overlapping connections (Long, 1958). National political systems fit into international political systems and are composed of numerous subsystems, some of which extend beyond national boundaries.

If this complexity is not decomposable analytically into smaller systems or susceptible to some relatively simple aggregation techniques, the theoretical problems of understanding social history are not easily accommodated within contemporary theoretical styles. For example, it may be rash to assume that errors in expectations have a normal distribution with a mean of zero. The allocation of attention may be critical to the flow of events. The responsiveness of the political system to environmental pressures may, at least in the short run, depend on the amount of slack in the system, and on the ways in which accounting numbers are produced and fudged. The system may not come close to trying to resolve conflict but simply attend sequentially to the demands placed on it (Cyert \& March, 1963). Learning may be superstitious, and fallacious rules of inference may persist for long periods (Nisbet \& Ross, 1980). At the limit, the connections between problems and solutions may be less dominated by a logic of causal linkages between means and ends than by the less problematic temporal linkages of simultaneity (Cohen, March, \& Olsen, 1972).

Theories of collective behavior most commonly simplify the potential morass of collective complexity by one of two classic routes. The first is statistical aggregation. In its usual guise, aggregation assumes that the factors affecting outcomes can be divided into two groups, one systematic and the other random. Thus, for example, we might assume that in a population of voters there are many factors affecting electoral choice. Some of those factors (e.g., income) have impacts on the vote that are strong and consistent across individuals. Other factors (e.g., specific policy issues) have impacts that are weaker or less consistent or less well understood. If we assume the latter factors can be treated as noise, that is, that they are independent, randomly distributed variables, the systematic factors will be clear in the aggregate results. In this way, conventional assumptions of aggregation impose a statistical order on the results.

The second classical simplification is the assumption of historical efficiency. Although the argument is usually associated with theories of natural selection and best specified in modern theories of population biology, the basic idea of historical efficiency is implicit in many modern theories. Regardless of the complexity or apparent anomalies of human behavior, historical processes are assumed to eliminate rules for behavior that are not solutions to an appropriate joint optimization problem. Thus, a prediction based on solving the optimization problem will correctly predict behavior, regardless of whether the actors involved formulate or solve that problem explicitly (Friedman, 1953). For example, we might predict the outcome of a complicated political negotiation by assuming that the actors are each acting rationally on the basis of complete information about each other and the world, even though we recognize that such assumptions are quite false as a description of individual behavior. 
Students of institutions suggest alternative theoretical simplifications for understanding complex political systems, most commonly the assumption of a political structure. By a political structure we mean a collection of institutions, rules of behavior, norms, roles, physical arrangements, buildings, and archives that are relatively invariant in the face of turnover of individuals and relatively resilient to the idiosyncratic preferences and expectations of individuals. In contrast to theories that assume action is choice based on individual values and expectations, theories of political structure assume action is the fulfillment of duties and obligations. The difference is important. In a choice metaphor, we assume that political actors consult personal preferences and subjective expectations, then select actions that are as consistent as possible with those preferences and expectations. In a duty metaphor, we assume that political actors associate certain actions with certain situations by rules of appropriateness. What is appropriate for a particular person in a particular situation is defined by the political and social system and transmitted through socialization.

Political structure simplifies a complex world for the individuals in it. It does not necessarily, however, simplify the problems of the political theorist. The complex intermeshing of rule-driven behavior may be just as difficult to unravel as the complex intermeshing of preference-driven behavior. As a result, there has long been a tendency to combine ideas of political structure with ideas of historical efficiency. If individual behavior is driven by rules within a political structure, then it is possible to imagine that historical experience accumulates over generations of individual experience. The information about that experience is encoded in institutional rules (Nelson \& Winter, 1982). This argument is a familiar one to political discourse. It has been a part of conservative doctrine for hundreds of years, forming a basis for defending both traditional rules of behavior and the existing political order.

The advantage to treating behavior as rule driven, in addition to its apparent consistency with numerous observations, is not that it is possible thereby to "save" a belief in historical efficiency; rather, it is that it leads more naturally than does treating behavior as optimization to an examination of the specific ways in which history is encoded into rules, and thus to making the idea of historical efficiency more attentive to the possible limiting conditions for efficiency, and more likely to generate interesting predictions about multiple equilibria or long time paths. In fact, the assumption of efficiency becomes mostly a matter of faith if the joint optimization problem cannot be specified or solved by the observer, or if it is impossible to identify the precise mechanisms by which historical experience is transformed into current action. Unless the process is specified, it is impossible to examine either the likelihood that a particular equilibrium will be achieved or how long it will take.

\section{Politics as an Interpretation of Life}

A conception of politics as decision making is at least as old as Plato and Aristotle. It is reflected in the language and concerns of political thought, from the earliest political philosophers through Bentham to Merriam and Lasswell. Who gets what and how? For the most part, contemporary theory in political science considers politics and political behavior in such instrumental terms. The intent of actions is found in their outcomes, and the organizing principle of a political system is the allocation of scarce resources in the face of conflict of interest. Thus, action is choice, choice is made in terms of expectations about its consequences, meanings are organized to affect choices, and symbols are curtains that obscure the real politics, or artifacts of an effort to make decisions.

Parts of the new institutionalism are challenges to this primacy of outcomes. These challenges echo another ancient theme of political thought, the idea that politics creates and confirms interpretations of life. Through politics, individuals develop themselves, their communities, and the public good. In this view, participation in civic life is the highest form of activity for a civilized person. The ideas find post-Hellenistic voices in J.S. Mill, Pateman (1970), and Lafferty (1981). Politics is regarded as education, as a place for discovering, elaborating, and expressing meanings, establishing shared (or opposing) conceptions of experience, values, and the nature of existence. It is symbolic, not in the recent sense of symbols as devices of the powerful for confusing the weak, but more in the sense of symbols as the instruments of interpretive order.

The primary source of the institutionalist challenge is empirical. Observers of processes of decision making regularly discern features that are hard to relate to an outcome-oriented conception of collective choice. The pleasures are often in the process. Potential participants seem to care as much for the right to participate as for the fact of participation; participants recall features of the process more easily and vividly than they do its outcomes; heated argument leads to decisions without concern about their implementation; information relevant to a decision is requested but not considered; authority is demanded but not exercised (Feldman \& March, 1981; March \& Olsen, 
1976). These observations are often reported as anomalies, as symptoms of some kind of perversity in the systems that were observed, paradoxical. The appearance of paradox, however, is a product of our theoretical presumption that the main point of a decision-making process is a decision. For many purposes, that presumption may be misleading. The processes of politics may be more central than their outcomes.

Politics and governance are important social rituals. In older worlds in which the major causal force producing historical experience was the will of the gods, social rituals were organized around ceremonies by which that will was discovered and influenced. Most contemporary developed societies, being somewhat more secular in their conceptions of causality, believe that experience is produced by a combination of natural laws and intentional human action. In these societies, therefore, social and political rituals are organized around the consultation of expertise and the making of decisions (Olsen, 1970). The procedures of decision that we observe are reflections and reminders of this modern, secular conception of the social order. They are signals and symbols of the appropriateness of events, not in the sense that what happened needs to be viewed as desirable or pleasant, but in the sense that what happened can be viewed as having occurred in the way things happen (Feldman \& March, 1981). The usual term is "legitimate"; but legitimacy may denote something narrower than is intended, for what rituals seek to establish is not only the moral virtue of events but also their necessity.

\section{Theoretical Research and Political Institutions}

Human actions, social contexts, and institutions work upon each other in complicated ways, and these complex, interactive processes of action and the formation of meaning are important to political life. Institutions seem to be neither neutral reflections of exogenous environmental forces nor neutral arenas for the performances of individuals driven by exogenous preferences and expectations. As a result, contemporary political theory is probably overly sanguine about the possibilities for a theory of politics that ignores political institutions.

For the most part, however, the relevant theoretical work remains to be done. It is interesting to suggest that political institutions and the society are interdependent, but that statement needs to find a richer theoretical expression. It is appropriate to observe that political institutions can be treated as actors in much the same way we treat individuals as actors, but we need more detailed demonstrations of the usefulness of doing so. There is good sense in noting that history is not necessarily efficient, but it would be of greater help if we were able to show the specific ways by which specific history-dependent processes lead to outcomes that are either non-unique or long delayed under some conditions. It is plausible to argue that politics is filled with behavior that is difficult to fit into a utilitarian model, but the plausibility would be augmented if we could describe an alternative model. And it is provocative to note the importance of symbols, ritual, ceremony, and myth in political life, but we cannot sustain the provocation without a clearer specification of how theories of politics are affected by such a vision.

Moving from the subtle judgments of empirical knowledge to an appropriate theoretical formulation is no easier in the analysis of politics than it is elsewhere. It requires not only further empirical studies but also theoretical research. By theoretical research we mean primarily the development of ideas, concepts, and models based on empirical observations and relevant to a behavioral understanding and prescriptive ordering of political life. The objective is not impossible. Thirty years ago, empirical students of organizations made two major criticisms of the existing theory of organizational decision making. The first criticism was that the theory made extraordinary time and information demands on organizations (March \& Simon, 1958; Simon, 1957a, b). Information and time were treated as freely available resources. To ask that all consequences of all alternatives be known precisely seemed unreasonable in the face of empirical evidence that organizations considered only a small number of alternatives, examined only a small number of consequences related to only a subset of organizational goals, and made relatively imprecise estimates.

The second criticism was that the theory assumed that all participants in an organization shared the same goals, or if they did not, that conflict among them could be readily managed through the terms of some prior agreement (Cyert \& March, 1963; March, 1962). In the case of a political organization, the agreement was a coalition contract, or constitution, by which all members of a coalition or polity agreed to be bound to the policies specified through bargaining or legislation. Thus, the familiar distinction between "politics" and "administration." In the case of an economic organization, the agreement was an employment contract by which employees, in return for the payment of wages, agreed to act as though they had the same goals as the owner or other legitimate policy maker. Empirical studies seemed to indicate that conflict was endemic in organizations and that it tended to be interminable rather than settled by prior agreements.

These criticisms began to have serious impact 
on formal theories of organized action when they were translated into useful theoretical statements through the development of information economics and theories of agency. Such theories consider information as a scarce resource subject to strategic action in a world populated by selfinterested rational actors. Ideas drawn from organizational studies of bounded rationality and internal conflict permeate modern economic theory in the form of discussions of moral hazard, asymmetric information, agency, signalling, and optimal information strategies (Hirshleifer \& Riley, 1979). Most students of organizations would argue that these theories are also incomplete, but it is clear that the earlier empirical criticisms have reformed theoretical thinking.

The new institutionalism would benefit from similar theoretical development if it could be accomplished. Like the early observations about bounded rationality and internal conflict, observations about the importance of institutions have generally taken the form of criticism of existing theoretical ideas rather than the delineation of an alternative set of precise theoretical concepts. Developing a comprehensive theoretical structure for institutional thinking is, of course, a prodigious and pretentious task, not one that will be undertaken here. We can, however, identify a few ideas associated with the new institutionalism that might warrant theoretical attention.

\section{Institutional Conceptions of Order}

Institutional thinking emphasizes the part played by institutional structures in imposing elements of order on a potentially inchoate world. Traditional political theory involved considerable attention to the order produced by political contracts and reflected in constitutions, laws, and other stable rules, or by a community of moral obligation, often inspired and buttressed by religious dogma (Berki, 1979; Waterstone, 1966). For the most part, modern political theory eschews such concerns and focuses on aggregation and historical efficiency superimposed on two other kinds of order: the order imposed by reason and the order imposed by competition and coercion. Reason is recognized in ideas of rationality and intentional action; it finds institutional expression in the hierarchical organization of means and ends (and thus in formally planned institutions). Competition and coercion are recognized in ideas of conflict of interest, power, bargaining, survival, and war; they find institutional expression in elections and policymaking. Theoretical research relevant to the new institutionalism would involve elaborating additional notions of political order. We believe it is possible to identify at least six such conceptions on which a modest amount of theoretical work might yield rewards.

Historical Order. The concept of historical order implicit in contemporary theory emphasizes the efficiency of historical processes, the ways in which history moves quickly and inexorably to a unique outcome, normally in some sense an optimum. An institutional theory would specify how historical processes are affected by specific characteristics of political institutions, and it would provide greater theoretical understanding of the inefficiencies of history, i.e., historical processes that do not have equilibria, take extended periods of time, lead to non-unique equilibria, or result in unique but suboptimal outcomes. Theoretical attention to the inefficiencies of history involves a greater concern for the ways in which institutions learn from their experience (Etheredge, 1976) and the possibilities that learning will produce adjustments that are slower or faster than are appropriate or are misguided. It involves trying to specify the conditions under which the sequential branches of history turn back upon each other and the conditions under which they diverge. It involves characterizing the role of standard operating procedures, professions, and expertise in storing and recalling history.

Temporal Order. In most theories of action, we assume things are ordered by their consequential connections. Means are linked to appropriate ends; causes are linked to effects they produce; consequences are linked to actions that lead to them and to preferences they affect; solutions are linked to problems they solve. Such concepts of order underlie theories of choice. Deviations from consequential order are viewed as interesting aberrations, disturbances of a system otherwise held together by the way wanting something leads to doing something connected to the want, and doing something leads to consequences related to the intention. Temporal order provides an alternative in which linkages are less consequential than temporal. Things are connected by virtue of their simultaneous presence or arrival. In a culture with a strong sense of monthly or yearly cycles or of birth cohorts, we should not be overly surprised by temporal order. In many human situations the most easily identified property of objects or events is the time subscripts associated with them. Thus, students of time allocation in organizations have observed the ways in which attention to problems seems to be determined as much by the time of their arrival as by assessments of their importance. A classic form of temporal order is found in queuing theory, although most discussions of queuing are embedded in a consequential structure in which queues are either indistinguishable or distinguishable only by their processing times. 
Endogenous Order. Much of contemporary theory emphasizes the way order is imposed on political institutions by an external environment. From this perspective, for example, power within a political system is determined by possession of resources in the environment, interests are determined by position in the external world, and coherence within an institution is assured by the exigencies of existence. Thus, order is effectively exogenous to the institution and does not depend on properties of the institution or processes within it. Students of institutions have suggested a number of ways in which internal institutional processes affect things like the power distribution, the distribution of preferences, or the management of control. As a result, they invite theoretical development of models appropriate for understanding the ways in which interests and preferences develop within the context of institutional action, the ways reputations for power evolve as a result of the outcomes of politics, the ways in which the process of controlling purposive organizations produces unanticipated consequences, and the ways in which the course of decision making within political systems systematically, and endogenously, results in illusions of success and failure.

Normative Order. It is a commonplace observation in empirical social science that behavior is constrained and dictated by cultural dicta and social norms. Although self-interest undoubtedly permeates politics, action is often based more on discovering the normatively appropriate behavior than on calculating the return expected from alternative choices. As a result, political behavior, like other behavior, can be described in terms of duties, obligations, roles, and rules. Such a description has not, however, been translated into any very compelling theoretical form. Some efforts have been made to rationalize normative rules, such as altruism (Kurz, 1978) and reciprocity (Axelrod, 1980), or to specify the conditions for their evolution (Axelrod \& Hamilton, 1981; Trivers, 1971). From an institutionalist perspective, such efforts are exemplary, but they tend to limit attention to the comparative statics of individual norms. A broader theoretical examination of normative order would consider the relations among norms, the significance of ambiguity and inconsistency in norms, and the time path of the transformation of normative structures. A theoretical understanding of such conventional norms as those surrounding trust and legitimacy seems likely to be particularly germane to political analysis.

Demographic Order. It is tempting for students of politics, as for students of other human endeavor, to find order defined in terms of the logic of their particular domain of interest. Thus, students of legislatures imagine that a legislature is best understood in terms of lawmaking, and students of courts imagine that a court is best understood in terms of adjudicating. Alternatively, a human institution can be studied and interpreted as the cross-section of the lives of the people involved. The idea that collective behavior can be understood as a mosaic of private lives links contemporary theoretical thought to similar ideas among qualitative students of human behavior and novelists (Krieger, 1983). A focus on institutional demography combines such a vision of organized life with attention to a property of individual lives that is itself a product of the institutional structure-the individual career (March \& March, 1978; Pfeffer, 1981b). The theoretical requirements include useful concepts of the ways in which organizations adapt through turnover, institutions are driven by their cohort structures, and the pursuit of careers and professional standards dictates the flow of events.

Symbolic Order. Students of formal organizations have called attention to the ordering force of symbols, rituals, ceremonies, stories, and drama in political life (March, 1981; March \& Olsen, 1976, 1983; Meyer \& Rowan, 1977; Pfeffer, 1981a; Pondy, 1978). Symbols permeate politics in a subtle and diffuse way, providing interpretive coherence to political life. Many of the activities and experiences of politics are defined by their relation to myths and symbols that antedate them and that are widely shared. At the same time, symbolic behavior is also a strategic element in political competition. Individuals and groups are frequently hypocritical, reciting sacred myths without believing them and while violating their implications. The traditional problem with such observations is not doubt about their veracity but about our ability to translate them into useful theoretical statements without excessive damage to their meaning. Theoretical development reflective of an institutional perspective would include an examination of the ways in which the tendencies toward consistency and inconsistency in beliefs affect the organization of political meaning, the ways in which "exemplary centers" (Geertz, 1980) create social order through ceremony, and the ways in which symbolic behavior transforms more instrumental behavior and is transformed by it. In particular, a serious theoretical understanding of myths, symbols, and rituals must include some attention to the dynamics of symbols, to the processes by which symbols shape the behavior not only of the innocent but of the society as a whole.

\section{Examples of Possible Theoretical Research}

Within these six conceptions of order, there are possibilities for theoretical research attentive to 
the insights of students of institutions. Such research is institutional in two respects: First, it is oriented to one or more of the institutionalist conceptions of order; second, it tries to illuminate how institutional and organizational factors affect political events. As examples, consider the following:

Example 1: Policy Martingales. Many models of history recognize that specific historical events involve elements of chance. The unique historical happening may be a draw from some probability distribution of possible events. Even in cases where chance, strictly considered, is not viewed as vital, any specific event is seen as the consequence of a complicated interweaving of factors impossible to predict with precision in a single case. In the independent trial version of such models, any specific historical event is subject to various kinds of random fluctuations but, in the long run, unlikely events at a particular time are balanced by different unlikely events at a subsequent time. The specific realizations of the historical process that comprise the events of today are independent of the specific realizations that comprise the events of yesterday. Each specific event of an unfolding history is relatively difficult to predict, but prediction is not improved by knowledge of the history of past realizations of that process.

It is possible to see political policymaking as an independent trial process. Suppose we think of policy as the result of bargaining among political actors with prior preferences and resources, but subject to trial-by-trial variation attributable to specific, unpredictable and uncontrollable factors. Then understanding the short-run outcomes of a policy process would depend on considerable detail of the specific situation. A student of institutions might well observe that the details of the way attention is organized, how alternatives are presented, what information is available, which participants are free from other demands, how institutional memory is consulted, and a host of other factors would affect the specific political policy adopted at a specific time. At the same time, however, such factors are irrelevant (or redundant) to understanding the long-term mix of policies. Such an understanding is possible simply from a knowledge of the underlying political process and any systematic institutional biases.

Not all policymaking processes are independent trial processes. Many of them seem to be more in the nature of martingales (Feller, 1950). Like an independent trial process, a martingale process is subject to chance variation, but the variations accumulate. What distinguishes a martingale is the property that the expected value of the process at one time is equal to the realization of the process at the preceding time. This property makes the specific path of history important to understand- ing current historical events. In effect, the chance fluctuations of history change the baselines of the next step of the historical process. Common descriptions of incremental policy processes make them appear to be in the nature of martingales. The distribution of possible outcomes from a policy process is pictured as resulting from competition and bargaining over incremental adjustments in the current policy; the policy actually adopted is a draw from that distribution. This martingale property of policymaking is not independent of institutional factors. Indeed, it seems a prototypic institutional characteristic. Policies, once adopted, are embedded into institutions. They are associated with rules, expectations, and commitments. By affecting attention and aspirations, they affect the future search behavior of political participants.

Martingales diverge more rapidly than do independent trial processes; that is, for a given amount of chance variation in each time period, the variance across possible outcomes after some number of periods will be substantially greater in a martingale. As a result, the precision with which specific realizations of the process can be anticipated is considerably less. Thus, policy martingales are related to, but not identical to, various less precise ideas of forks in history, of critical events that made a difference. There is a sense in which the first step is more important than any subsequent one, but it is a limited sense. In a martingale process all events are forks; the policy paths of two political systems with identical underlying political conditions will be radically different simply because of the way in which (possibly small) perturbations shift the focus of political pressure.

Example 2: Experiential Learning. It is a frequent observation of institutionalism that institutions accumulate historical experience through learning. The results and inferences of past experience are stored in standard operating procedures, professional rules, and the elementary rules of thumb of a practical person. These elements of historical knowledge have been portrayed both as forms of irrational retrogression and as carriers of wisdom, and it is not hard to specify environmental situations in which either characterization would be appropriate. What is less clear is whether we can model the processes of institutional learning. Although there have been some loose arguments that experiential learning will, in the long run, lead to the discovery and adoption of optimal strategies, little theoretical effort has been devoted to specifying precisely the conditions under which learning from experience leads to optimal behavior, or to relating those conditions to features of institutional structure or life. 
Consider the following simple model of learning (Levinthal \& March, 1982). A decisionmaking institution simultaneously learns along three dimensions. First it modifies its strategy; that is, it changes the likelihood of making one choice rather than another among the alternative activities available to it. Subjective success leads to increasing the chance of repeating a choice; subjective failure leads to decreasing the chance of repeating a choice (March \& Olsen, 1976). Second, an institution modifies its competences; that is, it changes the skill it has at the various activities in which it might engage. Competence at an activity increases with experience at it; it decreases with time (Preston \& Keachie, 1964). Third, an institution modifies its aspirations; that is, it changes its definition of subjective success. Aspirations move in the direction of past performance (Cyert \& March, 1963). It is clear that institutional factors affect several of the key features of such learning. The learning rates associated with the three kinds of learning are partly a function of features of the institution. The degree of loose coupling in an organization affects the precision with which choices are made, outcomes observed, aspirations expressed, and competences realized. Thus, it can be expressed as various forms of noise in the process. Organizational slack affects the degree of centralization in the organization, and thus the linkage among subunits.

The three dimensions of learning obviously interact. For example, learning of aspirations affects the definition of subjective success, and thereby affects the learning of strategies. Learning of competences affects performance outcomes, and thereby affects the learning of both strategies and aspirations. Learning of strategies affects choices, and thereby affects the learning of competences. The model can be explored to discover the circumstances under which it reaches an equilibrium, and, among those the circumstances, those under which it reaches an optimum. It can also be combined into more complicated structures of learning where the choices of one institution affect the outcomes of another (e.g., competition and cooperation), and where the learning institution is itself composed of learning subunits.

Example 3: Garbage Cans. Garbage-can models of organizational choice have been suggested as a representation of a particular temporal order. In the form most commonly discussed in the literature, the garbage-can model assumes that problems, solutions, decision makers, and choice opportunities are independent, exogenous streams flowing through a system (Cohen, March, \& Olsen, 1972). They come together in a manner determined by their arrival times. Thus, solutions are linked to problems primarily by their simul- taneity, relatively few problems are solved, and choices are made for the most part either before any problems are connected to them (oversight), or after the problems have abandoned one choice to associate themselves with another (flight). This situation of extreme loose coupling, called an open structure in the original discussions of the garbage can, has attracted most of the attention in the literature, and empirical studies have revealed decision processes that appear to approximate such an open structure (March \& Olsen, 1976).

Not all decision situations are quite so unstructured, however. We can characterize a choice situation in terms of two structures. The first is the access structure, a relation between problems (or solutions) and choice opportunities. The access structure may require, allow, or not allow a particular problem, if activated, to be attached to a particular choice. The second structure is the decision structure, a relation between decision makers and choice opportunities. This structure may require, allow, or not allow that a particular decision maker participate in the making of a particular choice. Access and decision structures can be imagined in any kind of arbitrary configuration, but two special forms have been considered formally. A specialized structure is one that is decomposed into substructures that are open. Thus, a specialized decision structure is one in which it is possible to divide choice opportunities and decision makers into subgroups and match the two sets of subgroups so that every decision maker in a particular subgroup of decision makers has access to every choice opportunity in the matched set of choice opportunities, but to no other. A hierarchical structure is one that expands access rights as a function of hierarchical rank. For example, in a hierarchical access structure, problems and choices are ordered, and each problem has access to choices of the same or lower rank. The differences made by these structures have been noted both formally (Cohen, March, \& Olsen, 1972) and empirically (Egeberg, 1981; Olsen, 1983), but the empirical and theoretical examination of garbage-can processes within access and decision structures that are not completely open is barely begun.

\section{Subtle Phenomena and Simple Theories}

These examples hardly exhaust the list. Empirical observations of reputations for power in politics suggest that such reputations depend heavily on the place of an individual in a political structure and on inferences about the relation between preferences and outcomes. Some simple models of the dynamic relations among reputations for power, institutional position, preferences, and social outcomes would provide a 
richer understanding of the ways in which power reputations affect politics. Empirical observations of post-decision surprises (i.e., deviations of realized outcomes from expected outcomes) suggest that there are systematic differences between the ways in which individuals experience the consequences of their actions and the ways in which institutions do. Some simple models of institutional expectations, choices, and post-decision assessments would clarify the occasions for expecting positive or negative surprises from deliberate action.

What characterizes all of the examples, as well as the others that might be added, is a relatively simple approach to institutional phenomena. The new institutionalism is often couched in terms of a contrast between the complexity of reality and the simplifications provided by existing theories, but theoretical research from an institutional perspective cannot involve the pursuit of enormous con. textual detail. It is constrained by the capacity or human (and artificial) intelligence to cope with complexity, and although that capacity seems to expand with time, the rate of expansion continues to be modest relative to the demands of a fully contextual and institutional theory. From the point of view of theoretical research, consequently, the new institutionalism is probably better viewed as a search for alternative ideas that simplify the subtleties of empirical wisdom in a theoretically useful way.

\section{Conclusion}

The institutionalism we have considered is neither a theory nor a coherent critique of one. It is simply an argument that the organization of political life makes a difference. Some of the things we have noted are fragments of ideas; others are somewhat more systematic in developing a theme or reporting a series of observations. They are held together by an awareness of a set of phenomena that are more easily observed than explicated. Insofar as the ideas are consistent, the consistency is sustained partly by ambiguity. Many of the core ideas seem plausible and have been durable, but plausible durability (as numerous students of the history of knowledge have observed) is neither necessary nor sufficient for good sense.

The new institutionalism is an empirically based prejudice, an assertion that what we observe in the world is inconsistent with the ways in which contemporary theories ask us to talk. Like other prejudices in knowledge, it may be wrong-headed or muddle-headed, but it may also be a useful continuation of that gentle confrontation between the wise and the smart that describes much of intellectual history. On the chance that it is the lat- ter, which of course does not exclude the possibility that it is also the former, we have tried to draw some possible implications for theoretical research in political science. They are, at best, theoretical directions suggested by a sympathetic appreciation of a tradition of institutionalist thought. Such an effort is a little like trying to write a useful commentary on Heidegger in the form of a Shakespearean sonnet. If it has virtue, it is in attempting to encourage talking about a subtle body of thought in a way sufficiently naive to entice the technically proficient.

\section{References}

Akerlof, G. A. The economics of social customs, of which unemployment may be one consequence. Quarterly Journal of Economics, 1980, 95, 749-775.

Ashford, D. E. Political science and policy studies: towards a structural solution. Policy Studies Journal, 1977, 5, 570-583.

Axelrod, R. More effective choice in prisoners' dilemma. Journal of Conflict Resolution, 1980, 24, 379-403.

Axelrod, R., \& Hamilton, W. D. The evolution of cooperation. Science, 1981, 211, 1390-1396.

Bachrach, P., \& Baratz, M. The two faces of power. American Political Science Review, 1962, 56, 947-952.

Becker, G. S., \& Stigler, G. J. De gustibus non est disputandum. American Economic Review, 1977, 67, 76-90.

Berger, S. (Ed.). Organizing interests in Europe: pluralism, corporatism, and the transformation of politics. Cambridge: Cambridge University Press, 1981.

Berki, R. N. State and society: an antithesis of modern political thought. In J. E. S. Hayward \& R. N. Berki (Eds.), State and society in contemporary Europe. Oxford: Martin Robertson, 1979.

Burns, J. M. Leadership. New York: Harper and Row, 1978.

Cohen, A. P. Two-dimensional man: an essay on the anthropology of power and symbolism in complex societies. London: Routledge and Kegan Paul, 1974.

Cohen, M. D., \& Axelrod, R. Coping with complexity: The adaptive value of changing utility. American Economic Review, 1984, 74, 30-42.

Cohen, M. D., March, J. G., \& Olsen, J. P. A garbage can model of organizational choice. Administrative Science Quarterly, 1972, 17, 1-25.

Crozier, M. The bureaucratic phenomenon. Chicago: University of Chicago Press, 1964.

Cyert, R. M., \& March, J. G. A behavioral theory of the firm. Englewood Cliffs, N.J.: Prentice-Hall, Inc., 1963.

Downs, A. An economic theory of democracy. New York: Harper and Row, 1957.

Easton, D. Political science. In D. L. Sills (Ed.), International encyclopedia of the social sciences. Vol. 12. New York and London: Macmillan and Free Press, 1968. 
Eckhoff, T., \& Jacobsen, K. D. Rationality and responsibility in administrative and judicial decisionmaking. Copenhagen: Munksgaard, 1960.

Edelman, M. The symbolic uses of politics. Urbana: University of Illinois Press, 1964.

Egeberg, M. Stat og organisasjoner. Bergen: Universitetsforlaget, 1981.

Enderud, H. The perception of power. In J. G. March \& J. P. Olsen (Eds.), Ambiguity and choice it $\rightarrow$ organizations. Bergen: Universitetsforlaget, 1976.

Etheredge, L. S. The case of the unreturned cafeteric $\rightarrow$ L trays. Washington, D.C.: American Political Science Association, 1976.

Evans, P., Rueschemeyer, D., \& Skocpol. T. (Eds.). Bringing the state back in. Report of a conference on research implications of current theories of the state. Unpublished manuscript, 1983.

Feldman, M. S., \& March, J. G. Information as signal and symbol. Administrative Science Quarterly, 1981, 26, 171-186.

Feller, W. An introduction to probability theory and it applications, Vol. I. New York: Wiley, 1950.

Friedman, M. Essays in positive economics. Chicago: University of Chicago Press, 1953.

Geertz, C. Negara: the theater state in nineteenthcentury Bali. Princeton, N.J.: Princeton University Press, 1980.

Hanf, K., \& Scharpf, F. (Eds.). Interorganizational policy making: limits to coordination and central control. London: Sage, 1978.

Hayward, J. E. S., \& Berki, R. N. (Eds.). State and society in contemporary Europe. Oxford: Martin Robertson, 1979.

Heclo, H. Modern social policies in Britain and Sweden. New Haven, Conn.: Yale University Press, 1974.

Heller, H. Political science. In E. R. A. Seligman \& A. Johnson (Eds.), Encyclopedia of the social sciences. New York: Macmillan, 1933 (1957).

Hirschleifer, J., \& Riley, J. G. The analytics of uncertainty and information-an expository survey. Journal of Economic Literature, 1979, 17, 1375-1421.

$\rightarrow$ Jessop, B. Recent theories of the capitalist state. In Cambridge Journal of Economics, 1977, 1, 353-373.

Kahneman, D. Bureaucracies, minds, and the human engineering of decisions. In G. R. Ungson \& D. N. Braunstein (Eds.), Decision making: an interdisciplinary inquiry. Boston: Kent, 1982.

Kahneman, D., Slovic, P., \& Tversky, A. (Eds.). Judgment under uncertainty: heuristics and biases. Cambridge: Cambridge University Press, 1982.

Katzenstein, P. J. (Ed.). Between power and plenty: foreign economic policies of advanced industrial states. Madison: University of Wisconsin Press, 1978.

Kjellberg, F. Political institutionalization. London: Wiley, 1975.

Krasner, S. D. Defending the national interest: raw materials, investments and the U.S. foreign policy. Princeton, N.J.: Princeton University Press, 1978.

Krasner, S. D. Approaches to the state: alternative conceptions and historical dynamics. Comparative Politics, in press.

Krieger, S. Mirror dance. Philadelphia: Temple University Press, 1983.

Kurz, M. Altruism as an outcome of social interaction.
American Economic Review, 1978, 68, 216-222.

Laegreid, P., \& Olsen, J. P. Byraakrati og beslutninger. Bergen: Universitetsforlaget, 1978.

Lafferty, W. M. Participation and democracy in Norway. Oslo: Universitetsforlaget, 1981.

Lave, C. A., \& March, J. G. An introduction to models in the social sciences. New York: Harper and Row, 1975.

Levi, M. The predatory theory of rule. Politics and Society, 1981, 10, 431-465.

Levinthal, D., \& March, J. G. A model of adaptive organizational search. Journal of Economic Behavior and Organization, 1982, 2, 307-333.

Long, $\mathbf{N}$. The local community as an ecology of games. American Journal of Sociology, 1958, 44, 251-261.

Luce, R. D., \& Raiffa, H. Games and decisions. New York: Wiley, 1957.

March, J. C., \& March, J. G. Performance sampling in social matches. Administrative Science Quarterly, 1978, 23, 434-453.

March, J. G. Bounded rationality, ambiguity, and the engineering of choice. Bell Journal of Economics, 1978, 9, 587-608.

March, J. G. The business firm as a political coalition. Journal of Politics, 1962, 24, 662-678.

March, J. G. Decisions in organizations and theories of choice. In A. H. van de Ven \& W. F. Joyce (Eds.), Perspectives on organizational design and behavior. New York: Wiley, 1981.

March, J. G. Politics and the city. In K. Arrow, J. S. Coleman, A. Downs, \& J. G. March (Eds.), Urban processes as viewed by the social sciences. Washington, D.C.: The Urban Institute, 1970.

March, J. G. The power of power. In D. Easton (Ed.), Varieties of political theory. Englewood Cliffs, N.J.: Prentice-Hall, 1966.

March, J. G., \& Olsen, J. P. Ambiguity and choice in organizations. Bergen: Universitetsforlaget, 1976.

March, J. G., \& Olsen, J. P. Organizing political life: What administrative reorganization tells us about government. American Political Science Review, 1983, 77, 281-296.

March, J. G., \& Shapiro, Z. Behavioral decision theory and organizational decision theory. In G. R. Ungson \& D. N. Braunstein (Eds.), Decision making: an interdisciplinary inquiry. Boston: Kent , 1982.

March, J. G., \& Simon, H. A. Organizations. New York: Wiley, 1958.

Masters, R. D. The biological nature of the state. World Politics, 1983, 35, 161-193.

Meyer, J. W., \& Rowan, B. Institutionalized organizations: formal structure as myth and ceremony. American Journal of Sociology, 1977, 83, 340-363.

Nelson, R. R., \& Winter, S. G. An evolutionary theory of economic change. Cambridge, Mass.: Harvard University Press, 1982.

Nisbet, R., \& Ross, L. Human inference: strategies and shortcomings of social judgement. Englewood Cliffs, N.J.: Prentice-Hall, 1980.

Niskanen, W. A. Bureaucracy and representative government. Chicago: Rand McNally, 1971.

Nordlinger, E. On the autonomy of the democratic state. Cambridge, Mass.: Harvard University Press, 1981. 
Olsen, J. P. Local budgeting: decision making or a ritual act? Scandinavian Political Studies, 1970, 5, 85-118.

Olsen, J. P. Organizational integration in government. In P. Nystrom \& W. Starbuck (Eds.), Handbook of organizational design. Vol. 2. New York: Oxford University Press, 1981.

Olsen, J. P. Organized democracy. Bergen: Universitetsforlaget, 1983.

Olsen, J. P., \& Saetren, H. Aksjoner og demokrati. Bergen: Universitetsforlaget, 1980.

Olson, M. The logic of collective action. Cambridge, Mass.: Harvard University Press, 1965.

Padgett, J. F. Hierarchy and ecological control it federal budgetary decision making. American Journal of Sociology, 1981, 87, 75-129.

Pateman, C. Participation and democratic theory. Cambridge: Cambridge University Press, 1970.

Pfeffer, J. Management as symbolic action: The Creation and maintenance of organizational paradigms. In L. Cummings \& B. M. Staw (Eds.), Research in organizational behavior. Vol. 3. Greenwich, Conn.: JAI Press, 1981(a).

Pfeffer, J. Some consequences of organizational demography: Potential impacts of an aging work force on formal organizations. In S. B. Kiesler, J. N. Morgan, \& V. K. Oppenheimer (Eds.), Aging: social change. New York: Academic Press, 1981(b).

Pondy, L. R. Leadership as a language game. In M. W. McCall, Jr. \& M. M. Lombardo (Eds.), Leadership. Durham, N.C.: Duke University Press, 1978.

Potter, A. L. Political institutions, political decay and the Argentine crises of 1930. Unpublished doctoral dissertation, Stanford University, 1979.

Pressman, J. L., \& Wildavsky, A. B. Implementation. Berkeley: University of California Press, 1973.

Preston, L. D., \& Keachie, E. C. Cost functions and progress functions: an integration. Americal $\rightarrow$ Economic Review, 1964, 54, 100-108.

Robins, R. S. Political institutionalization and the integration of elites. Beverly Hills, Calif.: Sage, 1976.

Scharpf, F. W. Does organization matter? Task structure and interaction in the ministerial bureaucracy. In E. H. Burack \& A. R. Negandhi (Eds.), Organizational design: theoretical perspectives and empirical findings. Kent, Ohio: Kent State University Press, 1977.

Schmitter, P., \& Lehmbruch, G. (Eds.). Trends toward corporatist intermediation. Beverly Hills, Calif.: Sage, 1979.

Selznick, P. Leadership in administration. Evanston, Ill.: Northwestern University Press, 1957.

Sharpe, W. F. Portfolio theory and capital markets. New York: McGraw-Hill, 1970.

Shepsle, K., \& Weingast, B. Institutionalizing majority rule: A social choice theory with policy implications. American Economic Review, 1983, 73, 357-372.

Simon, H. A. Administrative behavior. (2nd ed.) New York: Macmillan, 1957a.

Simon, H. A. Models of man. New York: Wiley, $1957 \mathrm{~b}$.

Skocpol, T. Political response to capitalist crises: neoMarxist theories of the state and the case of the New Deal. Politics and Society, 1980, 10(2), 155-201.

Skocpol, T. States and social revolutions: a comparative analysis of France, Russia, and China. Cambridge and New York: Cambridge University Press, 1979.

Skocpol, T., \& Finegold, K. State capacity and economic intervention in the early New Deal. Political Science Quarterly, 1982, 97, 255-278.

Skowronek, S. Building a new American state. Cambridge: Cambridge University Press, 1982.

Stephan, A. C. The state and society: Peru in comparative perspective. Princeton, N.J.: Princeton University Press, 1978.

Stigler, G. J. The theory of price (Rev. ed.) New York: Macmillan, 1952.

Therborn, G. What does the ruling class do when it rules? London: Verso, 1980.

Tilly, C. (Ed.). From mobilization to revolution. Reading, Mass.: Addison-Wesley, 1978.

Trimberger, E. K. Revolution from above: Military bureaucrats and development in Japan, Turkey, Egypt, and Peru. New Brunswick, N.J.: Transaction Books, 1978.

Trivers, R. The evolution of reciprocal altruism. Quarterly Review of Biology, 1971, 46, 35-57.

Waterstone, G. C. Order and counterorder. Dualism in western culture. New York: Philosophical Library, 1966.

Williamson, O. E. Markets and hierarchies. New York: Free Press, 1978.

Wolin, S. Politics and vision. Boston: Little, Brown, 1960.

Wright, H. T. Recent research on the origin of the state. Annual Review of Anthropology, 1977, 6, 379-397. 